DOI: https://doi.org/10.32839/2304-5809/2020-10-86-29

UDC 831.111'245.4

Maliy Natalia, Dyachenko Larysa

Donbas State Teachers' Training University

\title{
THE PECULIARITIES AND THE WAYS OF FORMING OF PROFESSIONAL MOTIVATION OF FUTURE DEFECTOLOGISTS IN EDUCATIONAL AREA
}

Summary. The article considers the formation of professional motivation in future speech pathologists. The importance of solving this issue is emphasized, because the work of a defectologist requires the presence of special characteristics in his personality, the formation of which is carried out during their training. Issues of personal development of the student and the formation of his readiness for future professional activity become the main in the outlined situation. The psychological and personal readiness of the specialist for professional self-realization in modern conditions is important. It is emphasized that the transformation of the requirements for professionals of different natural influences the solution of the question of the complex relationship of personal and professional development of the subject. The question of quality criteria for the training of future speech pathologists can not be considered separately from the requirements of a particular environment in which the specialist works. It is at the stage of professional training in the university begin to develop in a specialist-defectologist those values and motives that determine the success of his work in the profession, and for this it is necessary to study the formation of professional values and motives in the formation of future defectologists.

Key words: motivation, professional development, defectologist, students, educational space.

Малій Н.Ю., Дяченко Л.О. Донбаський державний педагогічний університет

\section{ОСОБЛИВОСТІ ТА ЗАСОБИ ФОРМУВАННЯ ПРОФЕСІЙНОЇ МОТИВАЦІЇ МАЙБУТНІХ ДЕФЕКТОЛОГІВ В ОСВІТНЬОМУ ПРОСТОРІ}

Анотація. У статті розглянуто питання формування професійної мотивації у майбутніх дефектологів. Підкреслено значущість вирішення цього питання, бо робота дефектолога вимагає наявність особливих характеристик в його особистості, формування яких проводиться під час їх професійної підготовки. Питання особистісного розвитку студента і формування його готовності до майбутньої професійної діяльності стають головними в окресленій ситуащії. Важливими є психологічна і особистісна готовність фахівця до профресійної самореалізації у сучасних умовах. Наголошено, що трансформація вимог, які пред'являються до профресіоналів різного закономірно впливає на вирішення питання про складну взаємозв'язку особистісного і професійного становлення суб'єкта. Питання про критерії якості професійної підготовки майбутніх дефектологів неможливо розглядати окремо від вимог, які пред'являе конкретна середовище, в якому фахівець працює. Період студентства - це одне з важливих періодів в процесі профресійного розвитку. У сучасній психологічній науці професійне і особистісне становлення студента в умовах навчання у вищих навчальних закладах розглядається в контексті підходу, орієнтованого, перш за все, на особистість студента і створення умов для розвитку її суб'єктності. Професійна діяльність у сфері корекційної педагогіки має свої психологічні особливості та передбачае вплив на педагога специфічних фракторів, у тому числі стресових, і пред'являе особливі вимоги до особистості майбутнього фрахівця-дефектолога. Трансформація і збагачення мотиваційних та ціннісно-смислових складових життевого світу особистості професіонала відбувається у процесі взаємодії з професійною культурою та у реальній життедіяльності, однією зі складових якої є особливим чином організований освітній простір. Саме на етапі профресійного навчання у вузі починають розвиватися у фахівця-дефектолога ті цінності і мотиви, які у майбутньому визначають успіх його діяльності у професії, а для цього необхідно вивчити процес становлення профресійних цінностей і мотивів у процесі формування особистості майбутніх дефектологів. Студентство як період професійного розвитку суб'єкта, з одного боку, несе у собі загальний вміст, закономірності, загальні для всіх професій, а з іншого - має розглядати специфічність окремої профресії. Виявлено, що мотивація студентів повинна проводитися на базі поєднання трьох процесів: наукового, навчального та виховного. Підкреслені характерні аспекти, на яких повинний базуватися навчальний процес майбутніх дефектологів Ключові слова: мотивація, професійне становлення, дефектолог, студентство, освітній простір.

The problematic of research. Nowadays 1 the need for highly qualified defectologist considers the need to form professional motivation on the university level. In life of every person, there is an experience of communication, contact with a person with disabilities. In most cases, at the same time, upon contact, a person develops negative emotions, such as anxiety and fear, due to helplessness, manifestations of a lack of intelligence. These impressions are imprinted in the memory for a long time and can determine the further attitude towards the profession of a defectologist, determining it to be unattractive. Also in modern society there are already established ideas of people with disabilities: these are people who occupy the lowest level in the social hierarchy, such people do not benefit society and are invaluable. At the same time, the choice of a profession always falls on a specialty that will be valuable in society and bring satisfaction. Low wages with high professional employment and often difficult working conditions are also a negative factor affecting the choice of the profession of a defectologist [2, p. 3].

The relevance of the study is beyond doubt, nowadays there is clearly negative attitude of society towards persons with disabilities. In order to 
change this attitude, the state implements various programs within the framework where the social adaptation of persons with special educational needs takes place. One of the directions of such programs is the training of high-qualified defectological personnel. Therefore, modern pedagogical science needs a detailed study of the features of training of future defectologists.

The aim of the research is to analyze the features of professional motivation in future defectologists in the process of educational work.

The object of the research is the professional motivation of future defectologists at the Institute of special education.

The subject of the research is the process of formation of professional motivation of future defectologists in the process of educational work.

Analysis of research and publications. Currently, modern researchers are increasingly raising the question of the formation of motivation of students of higher educational institutions (E.Y. Kochelaeva, A.V. Kalashnikova, O.V. Odegova, A.S. Krivonogova.

Motivation is one of the most important structural components of any activity. Therefore, professional motivation is considered as a set of human needs and goals, built in a certain hierarchy, necessary for the implementation of planned activities and for achieving the aims set in achieving professional competence [1].

The formation of professional motivation specifically for students of defectological faculties (special teachers and psychologists) is poorly reflected in scientific works, although many researchers in their works indirectly touched on this topic (M.I. Sergeev, N.M. Nazarova, L.F. Serbina, Z.N. Smirnova, N.A. Strogova, A.I. Zhivina, A.A. Dmitriev, S.M. Sokolova, A.M. Gendin, L.I. Dmitrieva, O.N. Usanova and others).

Presentation of the main material. Despite the negative reinforcement and negative factors accompanying the work of a defectologist, the number of applicants entering the program «Special (defectological) education» has increased. The above mentioned educational brunch is characterized by a variety of social and moral attitudes. At the same time, the aims of training do not always correspond to the level of intellectual development of applicants.

Therefore, the modern education system requires improvement in the field of the formation of professional motivation of students, the formation and consolidation of such personality qualities as tolerance, self-organization, responsibility. All these aspects may be provided by extracurricular activities, educational work in the system of higher education [5, p. 56]. The basis of educational work in a higher educational institution is not only the formation of the basis of the profession, the expansion of the student's professional profile, but also the development of creative abilities, social mobility and competitiveness. Therefore, educational work, being a system, is formed from various subsystems necessary to form the qualities of a future professional defectologist. The upbringing of the individual during the period of study at the university is the most important stage of the socialization of the individual, when the purposeful educational impact on the person of the upbringing system organized and regulated by society is basically completed. At the same time, this stage is also the beginning of that period in the life of an individual when a person as a whole completes the development of his life position.

There is an interconnection and interdependence of educational, scientific and educational work, which is determined by a whole set of qualities, attitudes and value orientations of the individual that determine the professional and social competence of a specialist [4]. For the formation of professional motivation of students, it is necessary to involve them in various types of activities: educational and professional. It may serve as an additional opportunity for self-improvement in the students' own practical training.

According to a number of experts P.Y. Galperin, A.N. Leontyev, A.M. Matyushkina, N.V. Samoukina, for the formation of an adequate understanding of students-defectologists about their future profession, it is necessary to take into account not only the pedagogical principles and axioms, but also the peculiarities of the psyche of students, as well as the peculiarities of personality formation [3, p. 78]. For the formation of motivation, it is necessary to take into account the presence of both external and internal motives. Internal motives imply the student's desire to develop in the learning process. External motives are formed from by parents, friends, the environment of society.

These are the so-called hints, directions, demands, coercions, etc. At the same time, a phenomenon is often observed when the study begins to act as a forced behavior and often meets internal resistance of the individual. That is why the leading ones are always the internal motives that stimulate the forces. They can influence personality in different ways, which can lead to different learning outcomes. The most pronounced external aspects in the motives of study for the sake of material reward and avoidance of failure [1].

The educational process is a complex type of activity, implying the formation of many motives that affect not only the individual person, but also form a complex motivational system of this person. Let's consider some of the ways of increasing the motivation among students of 1 educational institutions.

The process of motivating students by the teacher. For students, in contrast to schoolchildren, it is necessary to explain correctly the need for the knowledge that teachers give them. Here, the formulation "it should be done" or "useful in life" contributes to the loss of the student's interest in the educational process because student comes to higher education an institution primarily for the realization of oneself as a person in the field of professional knowledge, and not for the formal acquisition of knowledge. Therefore, it is important for the teacher to present correctly information that will be really useful in the future.

Incentives for results, not evaluation. The student must not only be interested in the subject, but also open up opportunities for the practical use of knowledge. In this case, integrated classes conducted by the teacher will be interesting, in which the connection between educational and special subjects is traced. The use of material for 
the development of students' erudition will be also highly effective.

A bunch of student-teacher. It is important to understand that the effectiveness of the educational process will be much higher when the student perceives the teacher not just as a teacher, but as a mentor who is ready to help not only in educational but also non-educational activities. The teacher, on the other hand, must form confidence in the strength of students, develop trusting relationships for further high-quality cooperation in the learning process.

Respect for students. Any student is a person who can demand respect for himself. D. Carnegie wrote: «...do not skimp on compliments, recognize the merits (even those that do not exist), advance positive changes. Then your pupil will have more opportunities to become what you want him to be. Give the other what you want from him» [5].

Get them interested. In order for students to attend classes, they need to be interested in these classes. To do this, during lectures and practical classes, it is possible to create certain conditions that involve the active participation of students in educational activities: so that students can defend their opinions, find several options for a possible solution to the problem, take part in discussions, solve them through the complex application of solutions known to them, etc.

Motivation by example. For the formation of professional motivation of students, it is necessary not only to arouse interest in the subjects studied. The teacher should become a personal example, which can be characterized as a punctual, benevolent person who seriously and responsibly performs his work, checks the control, independent and practical work of students on time.

Providing maximum freedom of choice to students. There is such a form of education as days of self-government, which are necessary for the formation of motivation for independent activi- ty of students. Here you can aim to develop criteria and a form for assessing your own knowledge and skills, a form for performing individual independent work, a topic for a report or a variant of an assignment. Participation in the educational process, as well as direct involvement in it, increases the motivation of students.

Encourage student success by demonstrating their achievement. Public praise, especially with a description of the merits and distinctive features, adds to the student's self-confidence, increases his internal motivation and the desire to achieve the same result again. Thus, teachers should create such conditions for studying in a higher educational institution, in which a student could in a short time learn not only theoretical aspects, but also acquire practical skills with their creative application in practice. Also, the main task of a higher educational institution is not formal training of students who will receive crusts, but professional students interested in working in their specialty and having solid and stable knowledge applied in practice [4].

Conclusion. So, the scope of application of knowledge on motivation is very extensive. And the result from the practical application of this knowledge really huge in various fields of professional activity. The formation of professional motivation is a complex process that includes the work of several structural units at different stages. The work on the formation of professional motivation should include not only university and faculty teachers, but also the parents of students, as well as the students themselves should be interested in getting a quality education, and not in formal obtaining a diploma. The formed system of human motivation has a great influence not only on his behavioral characteristics, but also, as a dynamic personality characteristic, on the structure of a person's personality as a whole.. Consideration of other pedagogical and psychological aspects of the formation of the personality of a future defectologist may become a prospect for further research.

\section{References:}

1. Vygotskiy, L.S. (1995). Problemy defectologii [The problems of defectology]. Moskva: Prosveshenie, 224 p. (in Russian)

2. Gamayuvova, A.N. (2009). Professionalnaya orientatsia pedagogov-defectologov na zdorovie-sberegayushuyu deyatelnost lichnosti [The professional orientation of educators-defectologists on the health keeping of a personality]. Moskva: Pedagogicheskoye obrazovanie i nauka, 340 p. (in Russian)

3. Rubinshtein, S.L. (2000). Osnovy obshey psihologii [The statements of psychology]. Sankt-Peterburg: Pier, 712 p. (in Russian)

4. Ambrukaitis, J. Training special educators: experiences and perspectives. L. Bridges, 1995. 140 p.

5. Lacey, P. Training for collaboration. B. ENA, 1996. 258 p.

\section{Список літератури:}

6. Выготский Л.С. Проблемы дефектологии. Москва : Просвещение, 1995. 224 с.

7. Гамаюнова А.Н. Профессиональная ориентация педагогов-дефектологов на здоровье-сберегающую деятельность личности. Москва : Педагогическое образование и наука, 2009. 340 с.

8. Рубинштейн С.Л. Основы общей психологии. Санкт-Петербург : Питер, 2000. 712 с.

9. Ambrukaitis J. Training special educators: experiences and perspectives. L. Bridges, 1995.140 p.

10. Lacey P. Training for collaboration. B. ENA, 1996. 258 p. 